\title{
Singing Sustenance: An Ethnographic Account of Village Songs and Community Development in Postwar Rural Japan
}

\author{
Eid-Ul Hasan \\ Institute for Advanced Social Research, Kwansei Gakuin University \\ 1-155 Uegahara Ichiban-Cho, Nishinomiya, Hyogo 662-8501, Japan \\ Tel: 81-798-54-4719Ｅ-mail: eidulhasan@gmail.com
}

Received: October 14, 2016 Accepted: November 11, 2016 Published: December 22, 2016

doi:10.5296/iss.v4i2.10154ＵRL: http://dx.doi.org/10.5296/iss.v4i2.10154

\begin{abstract}
This paper offers an ethnographic account of seven village songs associated with community development in postwar rural Japan. These songs belong to Oyama Town in the southern island of Kyushu in Japan, and were created by the local community members mostly between 1961 and 1965. In Japan the village songs in prewar period were rooted in daily village life, and sang the glory of nostalgia in the form of work songs, party songs, calendrical or communal festival songs. In the postwar period, however, village songs embraced modernity as their focal theme. These seven village songs, created during high growth days, are songs with a difference as they portray efforts to bring about community development, under the New Plum and Chestnut (NPC) movement, with plum and chestnut as main crops, against the backdrop of a strongly centralized policy oriented rural Japan. The research found that the village songs had encouraged and motivated a rural community like the Oyama Town to create a "sense of community" through shared values and common goal. By exploring these songs, the research also identified that the local government such as the town office, which acted as a legitimate vehicle either by nurturing the potential local human resources or by entrusting the responsibility of community development with the local employees, had played an important role in devising and materializing the common goal- the development of Oyama.
\end{abstract}

Keywords: village songs, community development, NPC movement, sense of community, local government, postwar rural Japan, Oyama Town 


\section{Introduction: Village Songs in Japan}

The aesthetics of music in Japan can be observed from both sides, outside and inside of music (Kishibe, 1966), that is to say, they can be examined in both etic and emic point of view. Musical aesthetics from etic approaches can be examined in terms of society and politics, religion and ideas, ethics and philosophy, etc., and when examined in emic approaches, the most basic idea of musical aesthetics is the idea of beauty (Ibid.). This beauty lies in furusato (a native place, home), and is full of musical repertoire. On the other hand, differences in Japanese songs arise from geographical conditions, the particular religion or the prevailing ideology with which they were associated (Ibid.). This in contrast, brings satisfying feelings of nostalgia to the people who are closely linked to these varied but unique experiences (Kishibe, 1966; Hughes, 2008).

Village songs in early Japan, which date back to the eighth century, used the terms hinaburi, hinauta, inaka-uta, kuniburi and kunibushi in the sense of rural customs (Hughes, 2008). However, a naïve Japanese villager, in most cases, might simply use the term uta (song) in classifying what they sing (Malm, 2000). Moreover, village songs in Japan are strongly linked to their places of origin, and can be classified as work songs, rice planting songs, wine or sake makers' songs, songs for entertainment at feasts or parties, songs for weddings and funerals, children's songs and cradle songs (Yato, 2003; Isaku, 1981; Nihon dentō bunka shinkō zaidan, 2005).

On the other hand, the term min' $y \bar{o}$ (people's songs) was created in the late nineteenth century as a direct loan-translation of the German term Volkslied, thanks to the writer Mori Ogai, who used the term in 1891 in translating the title of Meyer's Griechische Volkslieder (Machida, 1971; Asano, 1966, 1983; Malm, 2000; Hughes, 2008). Since then, it has become the equivalent to Japanese folk songs and stands in contrast with Western-derived fōku songu, which usually refers to all the non-Japanese folk music heard throughout Japan since the mid-twentieth century (Malm, 2000). The impact of mediascape, technoscape, ethnoscape, finanscape, ideoscape has also changed the social fabric of Japanese folk song (Appadurai, 1996; quoted in Hughes, 2008), and created a dichotomy between min'yō and fōku songu.

By the 1960s, the broadcast media, record companies, newspaper companies, publishers al1 had a significant stake in the min'yō world resulting Japanese folk song as a commodity as well as an industry (Hughes, 2008). Furthermore, new folk songs were created in order to attract more tourists (Malm, 2000). The birth of hozonkai (preservation societies) notion in the form of min'yō kinkyū chōsa (Emergency Folk Song Survey) was planned by the Ministry of Culture in the late 1970s to capture what they coined as the mukei bunkazai (Intangible Cultural Property) (Groemer, 1994).

\section{Community Development in Postwar Rural Japan}

In the last 100 years, Japan has rapidly changed from a primarily agrarian nation to an industrial powerhouse. During the period of high economic growth, many rural areas have been engulfed by urban encroachments and industrial development. In fact, it is often explicitly claimed that Japan's postwar economic miracle and urban development have been 
accompanied by a steady decline of vitality in its' rural areas (Matanle \& Rausch, 2011). The negative consequences of high economic growth led the development of the anti-modernization school in rural studies that stressed the importance of local autonomy, cooperation, egalitarianism, shared identity and the social viability in rural community (Goto, 1993).

In addition, recently Japan has witnessed a series of gappei (amalgamation) where small municipalities have merged with the larger cities. Another worrying factor is the increasing decline of rural population. The total population in towns and villages dropped from 45.8 million in 1920 to 34.6 million in 1960, 27.9 million in 1980 to 11.9 million in 2010. Despite the ongoing change and mounting problems, some communities in rural Japan have successfully preserved their existence by devising alternative ways to development, and are able to compete in the domestic and international market.

Now, what makes these communities work? And what makes these well-functioning communities function well? It is 'community capacity' that makes these communities work and function well. According to Chaskin et al. (2001):

"Community capacity is the interaction of human capital, organizational resources, and social capital existing within a given community that can be leveraged to solve collective problems and improve or maintain the well-being of that community" (Chaskin et al., 2001, p.7).

In other words, community capacity is the ability of a community to produce outcomes in society, which individuals and organizations produce as the result of their collective activities by utilizing available resources, i.e. human resources, physical, social and organizational resources, to them. Moreover, it has four community-level characteristics: (1) a sense of community; (2) commitment to the community among its' members; (3) the ability to solve problems; and (4) access to resources (Chaskin et al., 2001). Here, a 'sense of community' means a degree of belongingness of community among its' members and mutually recognized values, norms, and vision (McMillan \& Chavis, 1986).

A number of community development ventures in Japan like One Village, One Product (OVOP) Movement of Oita Prefecture; municipal grape-growing and wine-making of Ikeda, Hokkaido Prefecture; joint venture to stop depopulation and to increase income and employment opportunities in Meiho, Gifu Prefecture; tourism of Yufuin, Oita Prefecture; collaboration of welfare and tourism in Asuke, Aichi Prefecture, have adopted the "endogenous approach" to community development that focuses on the local resources of each particular area, and uses techniques created through local traditions and culture. It is more self-oriented as a particular area itself leads the way to development. Among these, the most widely known example is the One Village, One Product (OVOP) Movement (Note 1). In the late 1970s, Oita's indigenous industries were deteriorating and agricultural products (except for shiitake mushrooms) failed to compete at the national market. Under such backdrops, Hiramatsu Morihiko, the then Governor of Oita Prefecture, initiated the OVOP movement in 1979. The OVOP Movement encouraged the utilization of local human, material, and cultural resources in order to create value-added local specialty products and/or 
services that could compete both in the domestic and in the international market. This movement has also earned international recognition as many countries started to implement it. However, Hiramatsu's OVOP Movement had an antecedent. In 1961, almost two decades before his OVOP Movement, Yahata Harumi, the then village mayor of Oyama (Note 2) in the southern island of Kyushu in Japan, launched a New Plum and Chestnut (colloquially known as NPC) Movement as a way to community development (Note 3).

While many communities in contemporary rural Japan face uncertainties on their future, they still are resource abundant-land, water, air, green environment, culture, and tradition, and urban people as well as the state have vested interests on these resources. It is this contradiction that makes community development in rural Japan as an emerging research theme, yet very few ethnographic studies have appeared in the last two decades. Hence, I contend that the successful cases of community development like Oyama merit in-depth inquires, and need to be explored ethnographically.

\section{Research Method}

Based on ethnographic field studies, this paper documents seven unrecorded village songs of Oyama in English language, and discusses their historical backgrounds, socio-economic roles and significance in creating local identity and development in the community. I used ethnography as a method of data collection as ethnography helps ethnographer engage on those being researched and understand what causes and effects influence their viewpoints (Cook \& Crang, 1995). Furthermore, the central characteristic of ethnography is fieldwork, and field research comprehends the "real-life situations" (Burgess, 1982).

The research does not look at the notations, scales, beat, pitch, tempo or the rhythmic patterns, and neither it discusses the musical instruments used in performing these songs like the flutes, shamisen (three-stringed banjo-like, long necked lute), shakuhachi (end blown or vertical bamboo flute), drums, etc. in details.

During my Ph.D. fieldwork, one day when I was looking up the personal archive of Koda Kazumi; a former town office employee, I came across to an unpublished, tinny, tattered but very worth collection of seven village songs entitled kayōshū (Anthology of Verses) prepared by the then sommuka (General Affairs Department) of the oyamamachi yakuba (Oyama Town Office) in June 1994. This anthology with a wide repertoire of songs, unfortunately for some unknown reasons, never came out in published form. Given the oral nature of these village songs, if not properly documented, the social and cultural events behind them are hard to understand, and as most of them are known and sung by the octogenarians, the danger of the slow death of these songs remains high. At this point, I felt the need to explore and record these songs.

These songs are confined within the geographical limit to Oyama, and were mostly created between 1961 and 1965, with the exception of "Oyama Marching Song", which was created in 1969. Among these seven songs, six are kaeuta (parodies), and one is original song. After collecting these songs in an unpublished form, first, I crosschecked the written lyrics with the local residents mostly in their mid-sixties, and found some kanji (Chinese characters) used in 
these songs were written incorrectly. I participated in some informal gatherings with local octogenarians in order to explore the musical flavor of these songs. They were nostalgic, and showed spontaneous attachment to these songs. I tried to investigate the underlying meaning of every single verse of these songs through discussions with knowledgeable members of the community, literature reviews and English translations of the songs were done in order to explore their deeper meanings. I also made several visits to the places mentioned in these songs, and while translating always took an insider point of view.

The terms 'sustenance' and 'village songs' used in this paper need a few words of justification at this point. The word 'sustenance' literally means 'food'. However, for 'sustenance' in relation to village songs, in particular, I use it as a metaphor to emphasize the socio-economic development sought by the townspeople of Oyama. On the other hand, given the nature of the seven songs analyzed in this paper, and to limit my scope of research; I prefer the term 'village songs' to the contentious issues of minyo (folk songs).

\section{Singing Sustenance: Village Songs in Oyama}

At this juncture of the paper, a clarification of the question: why I analyzed the songs of Oyama is necessary. What is unique to Oyama? Located in Hita City in western Oita Prefecture and bordering on Fukuoka and Kumamoto Prefectures, Oyama is a small rural town surrounded by cedar-forested mountains. This town is located along the banks of the Oyama River, which divides the town into two parts: the East Oyama and the West Oyama. The town has little flat land; three quarters of its area is covered by sugibayashi (cedar forests), with half of the rest occupied by orchards. It is the birthplace of the highly successful One Village One Product (OVOP) venture.

Like many other villages in Japan, the prewar Oyama was a predominantly agricultural village. Rice and wheat were the main crops grown during this period. These crops were mostly grown for household consumption, and thus, the agriculture of prewar Oyama was primarily 'subsistence agriculture'. In the aftermath of World War II when economic development in Japan started, Oyama was still a small undeveloped rural community, and its' socio-economic conditions were badly affected by the massive flood of the typhoons in 1953. During this time, Oyama was the poorest of 58 municipalities in Oita Prefecture (Óyama-chō-shi hensan-i'inkai, 1995). In 1961, it took the initiative of the New Plum and Chestnut (NPC) movement under the guidance of the then village Mayor Yahata Harumi. The goal was to get rid of the abject poverty faced in the early postwar period. Unlike the many other rice producing communities in Japan, Oyama started marketing its' own special products in the form of plums and chestnuts.

Now let's look at the seven village songs in details. The first song is the Oyama bijyon no uta (Song of Oyama Vision). This is a parody of the arigataya bushi (Thanks Giving), sung by the famous Japanese singer Moriya Hiroshi. The original song is written by Hamaguchi Kuranosuke, and the music was composed by Mori Kazuya. This parody was created around 1961 to 1962 . The year 1961 was crucial, as in this year the central government of Japan enforced the nōgyō kihonhō (Agricultural Basic Law). Under this law, every household was asked to open up their agricultural land to an extent so that it could increase the rice 


\section{Al Macrothink}

Issues in Social Science

ISSN 2329-521X 2016, Vol. 4, No. 2

production up to sixty kilograms. However, this was difficult to materialize in a mountainous landscape like Oyama, where flat land suitable for rice cultivation was very few. The geo-climatic conditions were also against this new law. Oyama refused to adopt this new order from the central government. In contrast, under the then village mayor and the head of the $n \overline{o k y} \bar{o}$ (Oyama Agricultural Cooperative) (Note 4) Yahata Harumi, Oyama took a unique way of small scale and multi production farming: mukade (centipede) farming. The 'Song of Oyama Vision' sings the vision of creating a better future and overcoming poverty through community development.

\section{Ōyama bijyon no uta}

Sonchō no kōsō wo utaimashō / tebyōshi soroete hajimemashō / yonjyūgo nen wo mokuhyō ni / ōyama bijyon wo utaimashō

Kogane no mura ni suru tamenya / umekuri awasete gohyaku chō / tabako ni kaiko ni niwatori irete / ageru shūnyū ga hyakuman en

Ōyama meibutsu takusan gozaru / umekuri purasu ni burudōzā / ume wa ume demo ume dewa nakute / kodomo wo takusan ume to iu

Kodomo wo undara hoikuen ni irete / kāchan shigoto ni sei wo dasu / koreni tōchan funki shite / nomitai osake wo gaman suru

Yagate gakkō ni iku koro nya / kyōkasho tada ni sukūru basu / hara ga gūgū naru koro nya / kyūshoku sentā no hibikigō

Yagate dōro mo hosō ni natte / michi no ryōgawa hanazakari / kankyōseibi mo yukitodoki / tekkin sangai shinchōsha

Koreja madamada tarimasen / futokoro no guai ga samishiino / soreja kyūryō wo agemasuru / minna nikoniko hachiman en

Yagate teinen kitakoro nya / bonsai ijiri ni mago no mori / toshi wo tottara yōrōin ni itte / goneta ato niwa aseiriba yuki

And I translate:

\section{Song of Oyama Vision}

Let's sing the plan of our village mayor / with putting our hands together / and targeting to the year of 45 (1970 AD) / let's sing the Oyama vision

To make our village rich / with a 500 chō (496 hectares) of plum and chestnut land / and adding tobacco, silkworm and fowl / we shall improve our income to 100 man (1 million) yen

Our Oyama has many special products / like plum, chestnut and also the bulldozers / and our ume does not only stand for plum / but for birth to a large number of kids as well

We shall send our kids to the nursery school after they are born / and moms 
could work as a result / this will spur dads to work harder still / sacrificing even his favorite sake

By the time the kids commute to school / school bus will come and free text books / and when they will be hungry / the Hibiki lorry will provide school lunches

Before long our roads will become paved / and the street will be surrounded with flowers in full bloom on both sides / the surroundings will also be well prepared / with a newly government office building in reinforced concrete

But hang on, isn't there something unfulfilled? / As our pockets are not well-filled / then let's increase our wages / to a cheerful 8 man (80 000) yen

By the time when we will retire / we'd devote ourselves in cultivating bonsai and looking after grandchildren / as we grow older, we will go to elderly home / and to the Aseiriba (a crematory) after we will die

The first section of this song portrays the ten years plan, from 1960 to 1970, devised by the guidance of the then village mayor Yahata Harumi. Here, the year 1970 was taken as a benchmark of rural development in Oyama. The total land for plum and chestnut cultivation in Oyama was 496 hectares. This land was designed for a harvest of 80000 yen per month, and a total of one million yen was targeted for the annual income of each household through the cultivation of plums and chestnuts aided by the side income from tobacco, silkworm and fowl. This common goal was believed would help make Oyama rich. Next, the song depicts the pride of having unique products like plum, chestnut and the bulldozers-without which they would not able to work properly. Here the word 'bulldozers' has a dual meaning of enthusiasm over work and the symbol of overcoming laborious work in the steep hills. The later part of this section has a poetic touch as it pictures the need of young kids for uplifting the future of Oyama. This also gives us an indication that the Japanese population in the very remote hamlets was already in decline, and the socio-economic conditions had impacted on having more kids, especially, for economically poor community like Oyama.

The next two sections portray the picture of a developed community that Oyama people could cherish for. Once Oyama would be rich, they could afford their kids in sending to the nearby school, and the women could also help the men in work. This, as a result, would encourage the men to work harder even the expense of sacrificing their favorite liquor. The song also sings of an affluent educational environment with the access of free text books and community's own school bus. The school lunches would be carried by the Hibiki lorry-an imagined name, but has a connotation with locally prepared lunches. It then describes the well cherished road and public infrastructures in the community. During 1960s although Japan was experiencing the high speed economic growth, the disparities between big cities and small rural communities remained as major issues of concern. Oyama was no exception. The roads in Oyama were unpaved, and the physical environment of the community was poor.

The next section describes the increase of wages to the then village office employees. In 


\section{MInstitute Macrothink $_{\text {Int }}$}

Oyama, first, they planned to increase the income of the farmers (residents). Only after then the public office employees could increase their monthly salary to 80000 yen, which was equivalent to that of the farmers. This emphasizes the fact that in Oyama, common people are always considered as the first priority. Finally, the song sees the ending part of a life where after the retirement; people would pass their time with their grandchildren or would be staying in the elderly home. The song ends with a mixed feeling of melancholy and a sense of humor as it sings that after the death, one would go to the Aseiriba-a hamlet of Oyama Town where the early crematory was located, and rest in peace.

The second song is the Umekuri undō no uta (Song of Plum and Chestnut Movement). This is a parody of the hanagasa dōchü bushi (On My Way to Hanagasa), sung by the legend Japanese singer Misora Hibari. The lyricist and the music composer of the original song is Yoneyama Masao. This parody was created around 1961 to 1962.

In order to increase farmers' incomes, the first NPC movement-focused on the concept of hataraku (work) —was introduced in 1961 with plums and chestnuts as main crops. It was believed that without increasing incomes, it would not possible to lift the village out of poverty. The movement aimed to improve incomes, reduce hours worked and make farm works less difficult, which would guarantee a blissful life. The movement encouraged farmers to aim for a three-day holiday week. It also set labor standards for farmers of an eight hour working day and 180 working days per year. These standards were like a "dream" to the farmers since they used to work hard from morning to evening every single day (Advance Oita, 1987). "Song of Plum and Chestnut Movement" is oriented to this first NPC movement, and invites a-full-family active participation of every household in the community at this newly devised development venture.

\section{Umekuri undō no uta}

Korekore uchino otōsan / umekuri undō wa ikagadesu / damatteite wa wakaranai / takeyama sugiyama zōkiyama / hiraite uemasho ume to kuri / yagate hanasaku oirano sato ni / heiwana mura wo kizukimashō

Korekore uchino okāsan / umekuri undō wa ikagadesu / anataga oyome ni kitakoro wa / asa wa asaboshi yo wa yoboshi / kurō no taema wa nakatta ga I yagate tanoshii shütome gurashi / heiwana mura wo kizukimashō

Korekore uchino onēsan / umekuri undō wa ikagadesu / anatamo kotoshi wa manhatachi / yagate oyome ni yukutoki wa / tansu nagamochana naikeredo / minnade agemasu umekuri chokin / akarui katei wo kizukimashō

Korekore uchino otōto yo / umekuri undō wa ikagadesu / omaemo gakkōja yūtōsei / oreni yoku nita tsuyoi yatsu / minnade ueta ume to kuri / yagate kōkō daigaku mademo / yatteyarukara ganbare yo

And I translate:

Song of Plum and Chestnut Movement 
Hi father of this household / how about plum and chestnut movement / you must speak, we are waiting / let us go and open up / the bamboo, cedar and coppice in the mountains / and plant plum and chestnut / they will flower and bear fruit before long / and a peaceful and prosperous village will be for everyone

Hi mother of this household / how about plum and chestnut movement / when you came as a bride / from the morning till to the evening / you had constant work / but you will enjoy the life as mother-in-law before long (As a new bride will come to house) / and a peaceful and prosperous village will be for everyone

Hi elder sister of this household / how about plum and chestnut movement / you will be twenty this year / and before long you will go to marry / we can't afford you a wardrobe or an oblong chest then / instead, we will give you savings from plum and chestnut / and a bright family will be for you

Hi younger brother of this household / how about plum and chestnut movement / you are a good student / and a strong guy, like me / thanks to the plum and chestnut we have planted / we will admit you into high school and university before long / keep up the hard work

The first section of this song calls the heads of each household in Oyama, here the fathers, most of whom were rice farmers, to come and join the plum and chestnut movement by opening up the bamboo, cedar and coppice in the mountains. This, as the song suggests, would help create a prosperous and peaceful village in the years to come. The song then draws the attention of the mothers of each household in Oyama, and invites to join the campaign. By joining the campaign, the mother could earn money and it would help reduce her work load she used to bear when she came as a new bride to Oyama, and would enjoy the life as mother-in-law, for a new bride would come to her house before long as a result. Next part of the song calls the participation of daughters who would turn twenty and would soon get married, to participate in the plum and chestnut venture. The socio-economic conditions of Oyama at the time were not satisfactory, and rural people were not economically rich. The song portrays these well as Oyama people did not have enough money to afford their daughters to buy, for instance, a new wardrobe or an oblong chest in their marriage ceremonies. It was the savings from the plum and chestnut that the Oyama people could depend on and utilize when their daughters would get married. The last part of the song asks the sons of the each household of Oyama to come and be a part of the ongoing plum and chestnut campaign. It highlights the ambition towards higher study. The Oyama people hoped that with the help of the money from plum and chestnut their sons could fulfill their dreams, and could enroll in the university in the near future. It was hoped that a-full-family engagement with the village development venture, would ensure a happy family for the community members.

The third song is the Umekuriundo kazoeuta (Counting Song of Plum and Chestnut Movement). This is a parody of the gōki bushi (Song of Sturdy Spirit). The singer, lyricist and music composer of the original song are unknown. This parody was created around 1965. The song portrays the NPC movement, and has a connotation of shared values and pride of 


\section{Macrothink \\ Issues in Social Science \\ ISSN 2329-521X \\ 2016, Vol. 4, No. 2}

community.

\section{Umekuriundō kazoeuta}

Hitotsu tose / hitoni shirareta ōyama no umekuriundō no kazoeuta

Futatsu tose I futatsu no hashira wa ume to kuri tabako yōsan sosainado

Mitsu tose I minna awasete soshūnȳu hyakuman mokuhyō wo tasseisu

Yotsu tose / yomo no yamayama kodamasuru juenchizōsei bakkuhō

Itsutsu tose / imaja sono namo kenkaichi kōzōkaizen susumu mura

Mutsu tose / mudana rōryoku haijoshite suwasupurēyā ni kyūsuisha

Nanatsu tose / nagaresagyō wa shūkajō no yama womo nomikomu senkadai

Yatsu tose / yagate ōyama meibutsu wa puramuwain ni / chesunatto

Kokonotsu tose / konna ikigai aru mura ni umareshi / oira wa kahōmono

Totsu tose / tomoni susuman ibaramichi higanjōju no / sono hi made

Owari tose / owari nagoya wa shirode motsu / oyama mura wa oirade motsu

And I translate:

Counting Song of Plum and Chestnut Movement

First / counting song of the well-known plum and chestnut plantation in Oyama

Second / plum and chestnut are two pillars / and there are tobacco, silkworm, vegetables and so on

Third / aiming to achieve/ a total annual income of 100 man (1 million) yen all together

Fourth / to develop orchard area by using the backhoe/ echoes in all directions of the mountains

Fifth / now Oyama is number one in Oita prefecture / and village restructuring is in progress

Sixth / (we will) eliminate useless labor / using water jet spray and water supply truck

Seventh / work flows / at the pick-up place / as if it swallows / agricultural product sorting stand

Eighth / soon plum wine and chestnut / becomes the local specialty of Oyama

Ninth / we are lucky / to be born in this village where a life is worth living

Tenth / let us work together hard across thorny path / till the point when / we 
could fulfill our earnest wishes

Finally / a castle holds Owari Nagoya / but we will hold our Oyama village

The first three sections of this song depict an overview of the 'plum and chestnut' venture. By 1965 , this venture had already become popular to the other neighboring communities. In this venture, plum and chestnut successfully acted as the two pillars among other cash crops, like tobacco and silkworm, in achieving the goal of a total annual income of one million yen. The next two sections portray the mammoth task of opening up mountain lands for orchard farming all over Oyama, which the town office employees had been entrusted with (refer to the song Operāta kouta for more on this issue). In 1965, Oyama became 'number one' in Oita prefecture - the remnant of those hard works. The following two sections illustrate the attempt of eliminating useless labor in the form of mechanized agriculture or water supply truck for the restructuring work of Oyama. These helped increase the work flows, which could be seen in the agricultural product sorting stand. The last four sections of this song confirm that, by 1965, plum wine became dominant in the beverage menu. These sections also hail Oyama as a place where life was worth living, and call the local people to cooperate with each other until they could fulfill their mission. The song ends with promise that unlike Nagoya City, which is known for its castle, the future of Oyama would depend on common villagers - that is, the local human resources.

The next song, Oyyma ondo (Oyama Marching Song), depicts the beauty and fame of several historical places and events in Oyama, which the community members can be proud of, and hence, help build the sense of Oyama community among them. This is not a parody. This song was created around 1969. The singer of this song was Mihashi Michiya. The lyricist of this song is Kuwano Haruhiko and the music composer of this song is unknown.

\section{Ōyama ondo}

Warabi nobita kanē / taraibaru daini yō / kaoru shiitake nihon ichi nihon ichi

Senjō yanaba ninē / asagiri harete yō / haneru wakaayu se wo noboru se wo noboru

Hibiku taiko ninē / mikoshi ga uneru yō / ogamu oimatsu futaridzure futaridzure

Hadakamairi denē / kokoromo isamu yō / noboru ishidan karatomari karatomari

Momiji iromasunē / hibiki no se deyō / imamo misetai ikadanori ikadanori

Takitatō kara nē / hoshigabuchi mirebayō / hime no sugataka tsuki no kage tsuki no kage

Yume no kakehashi nē / ōyamagawa ni yō / heiwana mura wo kizukimashō / kizukimashō

And I translate:

\section{Oyama Marching Song}

Hey has the bracken grown enough / in the Taraibaru / and also Japan's number one 
fragrant mushroom

In the fish trap of Senjō / the morning mist shines / where the young ayu (a sweet-fish) jumps / and goes up stream, goes up stream

A drum echoes / omikoshi (a portable shrine) sways / praying at the Oimatsu / couple following couple

Going to worship naked / cheers up one's mind / climbing stairs at the Karatomari Shrine, climbing stairs at the Karatomari Shrine

Autumn leaves take colors / under the river Hibiki (Oyama River) / my mind still wants to show the raft riding, the raft riding

From the Takita Tower / looking at the Hoshigabuchi (a deep pool) it seems / shadow of a princess, or / shadow of the moon, shadow of the moon

Like a bridge of dream / in Oyama River / let us build a peaceful and prosperous village / let us build

The song first portrays the Taraibaru settlement. The land in this settlement is terraced field in nature. Japan's best fragrant mushrooms are found in this hilly area. The largest rhododendron park in Western Japan created by the local resident Koda Kazumi is also located in this settlement. It then describes the Senjo settlement, which is near to Oyama River - the upper reaches of Chiku River. In this river, young sweet-fish used to jump and go upstream in the midst of the morning mist. It also reminds the community members about the sacred places like the Oimatsu area and the Karatomari Shrine of Ogirihata. The Oimatsu area is renowned for a portable shrine where usually young couples come to pray. On the other hand, in the Karatomari Shrine, after going to worship naked, people climb stairs as a part of the ritual. The next two sections illustrate the natural beauty of Oyama. In past, raft riding in the river Hibiki (Note 5) was common. In autumn when the leaves take colors, one would feel nostalgic and perhaps would like to rearrange the raft riding one more time. Also, when looking at the Hoshigabuchi, name of a deep pool of the Oyama River in Matsubara settlement, from the Takita Tower (located in Matsubara); it resembles either with the shadow of beautiful princess or with the shadow of the moon. The last section of this song is about the future of Oyama, where the Oyama River would play the role of a bridge of dream. This dream was to build together a prosperous and blissful Oyama.

On the other hand, the next three songs portray the role and the contribution of the village/town office and its' employees to the development of Oyama community. The village or town office in Oyama is called as yakuba. After the amalgamation with the neighboring Hita City in 2005, the Oyama yakuba has been changed into 'Hita City, Oyama Promotion Bureau'. In the pre-NPC movement period, the yakuba was primarily responsible to recording population change through births and deaths, registering marriages and collecting taxes. At this time, there was a wide gap between the local government and the local farmers in Oyama. The yakuba showed little interest on the lives of farmers. The yakuba did not provide farmers any technical guidance and financial assistance on their production activities. 


\section{Macrothink}

In 1955, Yahata Harumi became the mayor. He served as the mayor of Oyama for 16 years thereafter. Under the leadership of Mayor Yahata Harumi, the yakuba became a crucial agent in development of Oyama. Yahata believed that the yakuba should function as a system that would lessen the gap between the farmers and the local government, and must provide necessary assistance to farmers to get rid of the socio-economic hardships. The yakuba provided guidance on how to deal with various cultivations along with funding assistance to the farmers of Oyama. The yakuba was the body through which subsidized plum seedlings were distributed to the farmers that decided to shift from rice agriculture to orchard farming in the first phase of the NPC Movement. Moreover, Yahata saw the yakuba as an ideal organizational vehicle for nurturing and mentoring the latent human resources of Oyama. Through the yakuba, he was able to exercise his leadership and was also able to influence and develop Oyama's future leaders in the younger employees of the yakuba.

The following village song, Shukuchoku no uta (Song of a Night Duty), is about the night duty of a yakuba employee. It portrays the beauty between duty and loneliness in a poetic manner. During the NPC movement, the employees of the yakuba in Oyama were required to perform a night duty in rotation basis. This song is a parody of the gādo shita no kutsumigaki bushi (Polishing the Shoes under an Overpass), sung by Miyagi Mariko. The lyricist of the original song is Miyagawa Tetsuo and the music was composed by Tone Ichirō. This parody was created around 1961 to 1962.

\section{Shukuchoku no uta}

Akai yūhi ga ōyama ni shizumya / sato nya chirahora hi ga tomoru / yūge no kemuri mo tachinoboru / oira samishii shukuchoku da / $\bar{a}$ à asu ninaranakya kaerarenu

Tsutome hatashite tokononaka / senbeibuton ni kurumareba / fui ni naridasu beru no oto / dareka kitakato tobiokirya / à à madonya chirahora hoshi ga deru

Shibashi madoromi yume utsutsu / tomo no yobukoe me wo samasu / kyō mo yaruzoto tobiokite / hōki katate ni tobidaseba I à à yane de suzume ga waratteru

And I translate:

\section{Song of a Night Duty}

The red sun sinks at Oyama / our village is teeming with lights / the smoke of supper rises / but I am on a lonely night duty / oh I can't go home until tomorrow

In the bed after finishing the duties / when I wrap up a thin futon / suddenly the bell rings / I jump up from the bed as if somebody has come / oh the window is covered in twinkling stars

I doze off for a while and go into a trance / a calling voice of a colleague wakes me up / I jump up from the bed; let's give it a go today as well / with a broom in one hand / oh a sparrow is chirping on the roof. 


\section{Al Macrothink}

The first part of the song echoes the feelings of a yakuba employee on a night duty. The loneliness encapsulates in the sinking sun and in its teeming lights. It illustrates that even the yakuba employee was hungry; he (in the 1960s it was a rarity to find women working in the public sectors like the yakuba) could not leave till the next morning. The next section of the song portrays the yakuba employee's affection for his work. After finishing all the duties, the employee would go to bed but could not sleep well as in the middle of the sleep he woke up as if somebody had come. The twinkling stars healed up him for a while. The last part describes the next morning events where the yakuba employee would wake up from bed, thanks to a calling voice of one of his colleagues. With a broom in hand-a daily morning routine to clean the floor, and greeted by the chirping sparrow; he would prepare himself for another new day.

The next village song, Operāta kouta (Ballad of an [Bulldozer] Operator), illustrates the responsibilities of a bulldozer operator who was also an employee of the yakuba, and worked not only in the desk of the yakuba but also in the severe conditions of mountain plateau in order to fulfill the common mission: the development of Oyama. This is a parody of the ozashiki kouta bushi (Party Song), sung by Satsuki Midori. The lyricist of the original song is unknown and the music was composed by Mutsu Akira. This parody was created around 1965.

\section{Operāta kouta}

Yakuba chōsha de jimu torumo / yama no daichi de ana horumo / tsutome ni kawariga aruja nashi / mura ni tsukusu wa mina onaji

Dōse otokonoko to umaretara / notte myanse bakkuhō / unaru enjin kodamasurya / ore no kokoro mo isamitatsu

Ennetsuritai wo tokasu hi mo / kōru enjin kokukan mo / nande kujiketenaru monoka / shimei hatasan sono hi made

Kinō wa higashi kyō wa nishi / yukue sadamenu mija totemo / teshio ni kakeshi ume to kuri / yagate hanasaki mimo naran

Boku ga yakuba ni inai tote / uwaki okosuna rinki suna / hito ni orarete chiru janashi / ame no furu himo nai janai

And I translate:

\section{Ballad of an [Bulldozer] Operator}

Working at the yakuba / or digging a hole in the mountain plateau / there is no change in the responsibility / everything is same for the sake of the village

After all we are young men / we ought to ride the backhoe / as the humming engine echoes / and spurs my heart on

Even on a sweltering day with melting heat / or an ice cold day when the engine freezes / don't be frustrated / as we have a mission to fulfill 
Yesterday was east, today is west / we head in all directions / as we take great care of plum and chestnut / eventually they will flower and bear fruit

Even if I am not in the office / don't flirt and don't be jealous / with other guys / as there are also rainy days (when I will be in office for you)

The first section of this song portrays the sense of responsibility of a yakuba staff assigned as a bulldozer operator. For the sake of the village's prosperity, the staff did not differentiate the works that he was assigned to. It then reflects his devotion towards duties. Given his age and energy, he would fulfill his duties with utmost care, and the echoes created by the humming engine of the backhoe would spur his heart on. The third section of the song portrays the unfavorable conditions like melting heat and freezing cold, in which the operator had to work hard as Oyama had a mission to fulfill, and much of it relied on his strong working hand. The next part of the song indicates the wide range of area that the operator had to cover on. He had to work back-and-forth, from the East Oyama to the West Oyama, to look after the Oyama's plums and chestnuts, which before long would flower and bear fruits. The last fragment of the song gives us a sense of humor, where the bulldozer operator gave a reminder to his female colleague (here, girlfriend!) for not to become so close with other male colleagues as he would not go out in mountains and would rather stay in office in rainy days.

The yakuba employees were also very proud of their duties. The following village song, Yakubashokuin no uta (Song of Town Office Employees), sings the triumph of the yakuba employees, who were selected for the rejuvenation of Oyama. This is a parody of the gunka. arawashi no uta bushi (War Song, Song of Violent Eagles), sung by Namioka Sōichirō. He was famous for singing various war songs, and was very popular in the late 1930s. The lyricist and the music composer of the original song is Azuma Tatsuzō. This parody was created around 1965, and was sung in firm chorus.

\section{Yakubashokuin no uta}

Mitaka yakubano kono shokuin / ōyama danjo no seiei wo / sugutte tsudotta kono warera / mura no kensetsu hikiuketa / kurunara kitemiro nankanji / bunbun orera de bunto tobuzo

Darega tsuketaka oyamano / na nimo hajinai kono chikara / amemo arashimo nanno sono / omoi shigoto wo kakaekomi / gun ken gurai wa hitomatagi / bunbun orera de bunto tobuzo

Ōnami konami wo norikoete / kumoranu tsuki koso waga kokoro / tenka no oyama shittaka to / kyōmo hagemu mura no tame / gokurō shikkari tanomuzo to I bunbun orera de bunto tobuzo

And I translate:

\section{Song of Town Office Employees}

Have you seen the employees of this village office / we are the wonderful men and women of Oyama / we are those who have been selected / for the 
construction of our village / if you have the courage come and take the challenge / we will roar and march on

We don't know who has given the name Oyama / it has a power as worthy as its name / even in the rain or in the storm / we can take on heavy work / county or prefecture level / with a spring in our step, we will roar and march on

In overcoming any major problems / we never give up / did you learn about the well-known Oyama / today we will give our best for the village / as our villagers are relying on and are thankful to us / we will roar and march on

The first section of this song depicts the glory of being an employee of the Oyama yakuba. Those who used to work there had a strong feeling of pride and honor to represent the village. Working for Oyama through the yakuba was seen as a prestigious job as the village restructuring work relied heavily on the village office employees. The middle section of the song portrays the fighting spirit of the yakuba employees. Employees of the yakuba saw their jobs challenging, and were always ready to compete with the other neighboring communities in any development related works that would benefit Oyama and the village people. The final section illustrates the commitment of the yakuba employees towards combating any kind of problems that it might encounter, and the gratitude to the local people for relying on them in every step of its' development process.

\section{Discussion: Village Songs and Community Development}

From the foregoing description of the seven village songs in Oyama, several features stand out. I consider these as important prerequisites for community development efforts in rural Japan, particularly for those communities with aging and depopulation problems.

Firstly, the seven village songs explored in this paper can be of three kinds: songs that portray the vision of community development through the NPC movement; song that sings the attributes of the locality; and songs that depict the responsibilities of the town office as well its' employees.

Secondly, it can be claimed that these songs had created a "sense of community" among the locals by disseminating common goal and developing shared values, which resulted in increasing the "community capacity" in Oyama. These are considered as important features for community development in community capacity approach (Chaskin et al., 2001; Miyoshi, 2010). For example, Oyama introduced the NPC movement as a way to development through crop diversification and shifting from the traditional central government-oriented rice farming to alternative orchard farming. The first NPC movement set a common target for gross household income at one million yen within ten years, and the labor standards of eight-hour working day with 180 working days annually as well as an income of 2000 yen daily_all of which were "like a dream" to the farmers (Advance Oita, 1987).

Thirdly, these songs indicate that the community members were proud of their community. Their community characteristics were seen unique, and thus, a sense of belongingness and shared values were developed among the community members. A high level of participation 
by the community members were seen as various collective activities had flourished at the village level for the first time in Oyama.

Fourthly, it can be observed that the local government like the yakuba (town office) acted as a legitimate agent for development either by nurturing the potential local human resources or by entrusting the responsibility of community development with the local employees. For example, the yakuba secured finances and human resources through budget allocations and relocating staff required for the NPC movement. The yakuba also developed infrastructures such as the access roads to farmers' farmlands and road building machineries as well as provided necessary guidance on how to deal with orchard cultivations along with funding assistance to the first-time orchard farmers. On the other hand, the yakuba employees were also inspired with the Oyama vision, and would often get together and discuss on the development of Oyama.

Fifthly, this research suggests that the development in Oyama is community oriented. The village songs were created by and used the perspective of local community members in order to create more prosperous and peaceful environment deemed necessary for the development of Oyama.

Finally, since most of the village songs discussed in this paper are kaeuta (parodies) in nature, the credibility of these songs need to be clarified. Unlike some other parodies in contemporary Japan, these parodies were created as the media of social change (here, community development) and as discussed in the earlier sections, they do not lack seriousness. The parodies analyzed under the name of village songs in this paper are distinct in nature.

\section{Conclusion}

In this paper, I looked at seven village songs and community development efforts. Exploring community development through the lens of village songs gives us a new dimension of community development study. I looked at how Oyama had transformed from rice farming to orchards (plums and chestnuts) farming community during the postwar period. To begin with, Oyama recognized increasing farmers' incomes as the prerequisite for overall development. Crop diversification was deemed necessary in order to increase the farmers' incomes. However, this was in total contrast to the national agriculture policy in postwar Japan. In order to attain high-income as well as affluent life for the villagers Oyama introduced the NPC movement.

I also identified that Oyama is not blessed with natural resources, and the area of this town is quite small comparing to the neighboring towns. Moreover, it does not have a vast farmland, and the topography is steep with very few flat lands. Except agriculture there were no other industries in this town. The town, in the past, was not prosperous. Under such backdrops, Oyama went from being the poorest in Oita Prefecture to become economically wealthy, harmonious and culturally rich community. The village songs succeeded in encouraging local people to share a common vision of the Oyama community. Furthermore, the nostalgic remnants of village songs help build the sense of belongings, and create identities among the 
community members. The songs describe that both the local government in the form of yakuba (the town office) and the yakuba employees, most of whom were local residents and knew the community well, had played an important role in devising and materializing the common goal - the development of Oyama. These songs were created and sung within the local community that holds rich history. It is also intriguing that residents were proud of their community, and always looked for opportunities to improve their town. These are important lessons that these village songs offer for community development in rural areas-particularly for those communities struggling for development due to the problems like aging and depopulation.

\section{Acknowledgement}

This paper is a part of my Ph.D. dissertation, and an earlier version of this paper was presented as an oral presentation at the 18th Japan Studies Association Annual Conference, Honolulu, Hawaii in 2012.

\section{References}

Advance Oita. (1982). Ōyama dokuritsukoku (Autonomous Oyama). Oita: Advance Oita.

Advance Oita. (1987). Niji wo ou gunzō (The Rainbow Chasers). Oyama, Hita: Oyama Agricultural Cooperative Association.

Appadurai, A. (1996). Disjuncture and Difference in the Global Cultural Economy. In his Modernity at Large: Cultural Dimensions of Globalization. Minneapolis: Univ. of Minnesota Press.

Asano, K. (1966). Nihon no min'yō (Japanese Folk Song). Tokyo: Iwanami Shoten.

Asano, K. (Ed.). (1983). Nihon min'yō daijiten (Great Dictionary of Japanese Folk Song). Tokyo: Yūzankaku.

Burgess, R. G. (1982). Field Research: A Sourcebook and Field Manual. London: Allen and Unwin.

Chaskin, R. J., Brown, P., Venkatesh, S., \& Vidal, A. (2001). Building Community Capacity. New York: Aldine De Gruyter.

Cook, I., \& Crang, M. (1995). Doing Ethnographies. London: Sage.

Goto, J. (1993). Rural Revitalization (Chiiki Okoshi) in Japan: A Case Study of Asuke Township (Unpublished doctoral dissertation). University of California, Los Angeles.

Groemer, G. (1994). Fifteen Years of Folk Song Collection in Japan: Reports and Recordings of the "Emergency Folk Song Survey". Asian Folklore Studies, 53(2), 199-209. http://dx.doi.org/10.2307/1178643

Hasan, E. (2012, January). Singing Sustenance: An Ethnographic Account of Village Songs and Rural Sustenance in Kyushu, Japan. Paper presented at the 18th Japan Studies Association Annual Conference, Honolulu, Hawaii.

Hasan, E. (2015). Oyama: An Ethnography of Rural Development and Change in Postwar 
Japan (Unpublished doctoral dissertation). Ritsumeikan Asia Pacific University, Beppu, Oita.

Hiramatsu, M. (2006). Chihō jiritsu e no seisaku to senryaku (Polices and Strategies for Regional Independence). Tokyo: Toyo Keizai Inc.

Hiramatsu, M. (2008). The One Village One Product Movement: Spreading throughout the World. Oita: Oita OVOP International Exchange Promotion Committee.

Hughes, D. W. (2008). Traditional Folk Song in Modern Japan: Sources, Sentiment and Society. Kent: Global Oriental Ltd.

http://dx.doi.org/10.1163/ej.9781905246656.i-408

Isaku, P. R. (1981). Mountain Storm, Pine Breeze: Folk Song in Japan. Arizona: The University of Arizona Press.

Kishibe, S. (1966). The Traditional Music of Japan. (1st ed. ). Tokyo: The Japan Foundation.

Machida, K. (1971). Min'yō (Folk Song). Tokyo: Shōgakkan.

Malm, W. P. (2000). Traditional Japanese Music and Musical Instruments. Tokyo: Kodansha International.

Matanle, P., \& Rausch, A. S. (2011). Japan's Shrinking Regions in the 21st Century: Contemporary Responses to Depopulation and Socioeconomic Decline. Amherst, New York: Cambria Press.

McMillan, D. W., \& Chavis, D. M. (1986). Sense of Community: A Definition and Theory. Journal of Community Psychology, 14, 6-23. http://dx.doi.org/10.1002/1520-6629 (198601)14:1<6::AID-JCOP2290140103>3.0.CO;2-I

Miyoshi, K. (Ed.). (2010). Chiikiryoku: chihō kaihatsu wo dezain suru (Community Capacity: Designing Rural Development). Kyoto: Koyo Shobo.

Nihon dentō bunka shinkō zaidan (Japan Traditional Cultures Foundation). (2005, Digital Audio). Nihon minyō: Marukajiri hyaku (Japanese Folk Songs: A Complete One Hundred Bites). Tokyo: Victor Entertainment Inc.

Ōyama-chō-shi hensan-i'inkai (Oyama Town Record Editorial Board). (1995). Öyama-chō-shi (Oyama Town Record). Oyama, Hita: Oyama Town.

Yahata, H. (1988). Nōkyō wa chiiki de nani ga dekiru ka (What Can Agricultural Cooperatives Do in the Regions). Tokyo: Ienohikarikyōkai.

Yamagami, S., \& Fujimoto, T. (2006). Isson ippin undō no genten, Ōyama-chō ni okeru chiiki shinkō (Rural Revitalization in Oyama Town: The Archetype of the One Village One Product Movement). In K. Matsui, \& S. Yamagami (Eds.), Isson ippin undō to kaihatsutojōkoku: Nihon no chiiki shinkō wa dō tsutae rareta $k a$ (One Village One Product Movement and Developing Countries: How were lessons from Japan's Rural Revitalization Transferred) (pp. 19-40). Chiba: IDE-JETRO. 


\section{Macrothink}

Yato, S. (2003). Warabe-uta ya minyōshū (Lullabies and Collection of Folk Songs). Matsue: Ōmoto Suppan.

\section{Notes}

Note 1. For a detailed account on One Village One Product (OVOP) movement, see Hiramatsu (2006, 2008), Yamagami \& Fujita (2006) and Miyoshi (2010).

Note 2. Oyama was a village until January, 1969. On 1 February, 1969, based on the machi-seido (town system), Oyama Village turned into present-day Oyama Town (Ōyama-chō-shi hensan-i’inkai, 1995).

Note 3. NPC Movement has three phases: the New Plum and Chestnut (NPC I) movement, the Neo Personality Combination (NPC II) movement, and the New Paradise Community (NPC III) movement. For more detailed works on NPC movement, refer to Advance Oita (1982), Yahata (1988) and Hasan (2015).

Note 4. In 1949 the Oyama-machi Agricultural Cooperative (nōkyō) was formed, and in 1954 Yahata Harumi became the cooperative head. Despite the merger with Hita City, Oyama Agricultural Cooperative still remains an independent agricultural cooperative.

Note 5. Hibiki is the secular name of the vicinity of the Oyama River. 